\title{
微細作業を支援するためのマスタスレーブー体型ツールに関する研究*
}

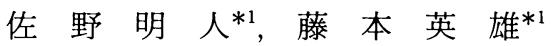

\section{A Study of Combined Master-Slave Tool for Micro Manipulation}

\author{
Akihito SANO and Hideo FUJIMOTO
}

\begin{abstract}
Humans can master the skill of micro manipulation which differs from the simple task of positioning through experience and years of training. Since the human ability is not quantifiable, it is impossible to substitute completely human ability for a robot. However, it is necessary to develop effective and suitable methods that lead to easy execution of micro manipulation in order to reduce exhaustion. Telerobotics and master-slave technology are useful methods for solving this problem. In this study, a new system that combines the master and the slave structurally is proposed. This combined master-slave system is designed as a compact tool which can be manipulated easily by the fingertips. Maneuverability of the master tool is improved by suspending itself electromagnetically. An electromagnetic sucking force is also used as a driving force of the master. In this study, a stabilized control of the electromagnetic suspension system and a bilateral control of the masterslave system are accomplished simultaneously. Furthermore, the validity of the developed masterslave tool is confirmed by control experiments.
\end{abstract}

Key Words : Micro Manipulation, Master-Slave System, Electromagnetic Suspension System, Quadratic Stabilization Design, Bilateral Control, Indirect Force Control

\section{1.はじめに}

近年, 工学分野におけるマイクロマシン開発, 医療 分野におけるマイクロ外科手術, 科学分野における細 胞操作などに, 微細作業(マイクロマニピュレーショ ン)技術の応用が積極的に進められている(1). 人間は, 長い経験と訓練によって高度な(単純な位置决め作業 とは異なる)微細作業が行えるだけの十分な技を身に 付けることができる. しかし一方で, 微細作業が容易 に行え, しかも長時間の作業でも疲労が少なくなるよ うな手段を開発することが重要であることがわかる. この人間の高度な技能を完全にロボットに置き換える ことは, 現在の技術では困難である。そこで, マス夕 スレーブシステムが, この問題を解決する有力な手段 の一つであると考えられる(2)(3).

人間が微細な作業を行う場合, 指先の触圧覚や滑り 覚などの指先感覚と, 腕の筋肉緊張による関節感覚を 複合して用いているといわれている(4).したがって, 多自由度のリンク機構からなる大型のマスタアームを 用いることは, 関節感覚を主として用いることになる ために, マイクロマニピュレーションには不適切であ

\footnotetext{
* 原稿受付 1996 年 6 月 12 日.
}

*1 正員, 名古屋工業大学 (画 466 名古屋市昭和区御器所町).
る. 佐藤ら ${ }^{(4)}$ は，力の高応答性を目的としたペン形の マスタマニピュレータを開発し, 指先圧覚と関節感覚 を複合することで, 広いダイナミックレンジの力制御 を行っている. 中尾ら(5) は, 内耳周辺の疾患に対する 手術に注目し, $10 \mathrm{mN}$ オーダの力制御を必要とする 顕微鏡下における骨片除去作業用に, ピエゾ素子を用 いた小型の工具を開発している.しかし，いずれもそ の力制御方式についてあまり詳しく検討されておら ず, 制御対象あるいは対象物の特性が変化する場合な どに, 安定的に力制御が可能かなどの疑問が残る.

従来のマスタスレーブシステムでは, 同じ形状, サ イズの 2 台のマニピュレータを別々の場所で用いる場 合がほとんどであった。近年, 異構造型のマスタスレ ーブが開発されたり ${ }^{(6)}$ ，一体化を図った研究が見られ る. Kazerooni(7) は, Extender(倍力装置)によって, 装置に作用する力をスケールダウンして, 装置の中に 入れた腕に直接提示している(人間が倍力装置の一部 となる). Extender は, マスタ・スレーブそれぞれに アクチュエータを置く必要がないことから, 従来のマ スタスレーブとは区別されている。 また, 福田ら ${ }^{(8)}$ は, 人間がロボットアーム先端に取付けられている操 作用センサを直接手で持って動作指令を与えることが できるマン・ロボット協調作業型のマニピュレータを 
提案している。これは，機能面でマスタとスレーブを 一体化したものである. 小菅ら ${ }^{(9)}$ は，機械系を道具と 同一の特性をもつように制御している。

本研究では，簡単に扱える小型の道具(ツール)をイ メージして, マスタとスレーブが構造的・機能的に一 体となった新しい夕イプのシステムを提案する。ま た，小型化を図ることで，高応答のアクチュエータに よる高いダイナミックレンジを確保する.さらに, マ スタ・スレーブそれぞれが，アクチュエータおよび 力・位置センサを一組備える、基礎実験用に開発した システムは, 電磁石による吸引力を使って, ツール自 身を磁気浮上させることで操作性を高めている．この 吸引力は, マスタの駆動力としても利用される，2 章 では，マスタスレーブ方式において，必ずしも遠隔操 作にこだわる必要がなく，同所性，同時性の利点を利 用して，マスタとスレーブを一体化することの意義に ついて述べる．3章では，提案するツールへの磁気浮 上系の採用, 構造, 操作方法について詳しく述べる. 4 章では, 磁気浮上系の安定化制御として, 近年注目さ れている $H_{\infty}$ 制御理論(10)(11) に基づく二次安定化補償 器の設計問題について議論する．5章では, バイラテ ラル制御方式について述べ, 実験によりその有効性を 確認する。

\section{2. マスタスレープ}

$2 \cdot 1$ 同所性および同時性 マスタスレーブ方式 は, 遠隔操作の一つの有力な手段として研究されてき た. 宇宙空間, 海底, 火災現場, 原子力施設内など人 間が直接立入ることができない場所での作業を，空間 的に隔たった安全なオペレー夕室から遠隔操作で実行 しょうというものである。このとき，マスタとスレー ブは, 図1(a)に示すように基本的に分離し，ある距 離隔たっている(非同所性, 非同時性)。また, 近年注 目されている遠隔外科手術 (辺地, 遠洋航海船, 戦場で の手術)でも，このようなマスタスレーブシステムの 応用が検討されている(12).

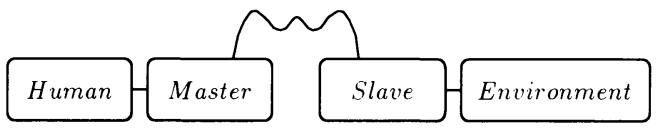

(a) Separate type

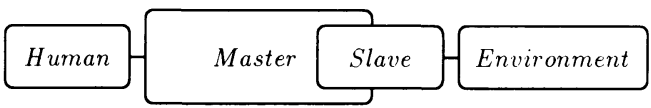

(b) Combined type

Fig. 1 Master-slave system
一方，作業目的によっては，必ずしも遠隔操作のス タイルを採る必要はない. 図 1(b)は, マスタとスレ ーブが機構的に一体となっているものである(5)(13). マ スタとスレーブが一体化しているということは，操作 者はスレーブおよび対象物と同じ空間を共有している ことを意味している(同所性, 同時性).したがって, その空間で起きるさまざまな現象を直接知ることがで き，隔離された場合に必要であった情報の伝達ならび に高レベルの提示の一部を行わなくてもすむ. 例え ば，手術は常に緊迫した状況下で行われるため, 医師 や看護婦は患者のわずかな異変にすばやく対処しなけ ればならない.したがって，できれば医師は患者のす ぐそばで手術を行うことが望まれる(14) (現行のスタイ ルの踏襲)

$2 \cdot 2$ マスタスレーブー体型人間が, 小型の道 具を使って微細な作業を行う場合, 时や手の側面を台 につき, 対象物を上からのぞく姿勢で, 慎重に位置を 合せて，指先にかかる力を細やかに制御する。また， 人間は, 低可動範囲・高感度の皮膚感覚と高可動範 囲・低感度の深部感覚を統合して, 高可動範囲・高感 度の感覚を実現している(4).このことから, 広いダイ ナミックレンジで力の制御をするには, 指先で作業す るのが妥当である，したがって，多自由度のリンク機 構からなる大型のマスタマニピュレータを用いること は, マイクロマニピュレーションには不適切である.

本研究では, 簡単に扱える小型の道具 (ツール)をイ メージして, 新しいタイプのマスタスレーブシステム を開発する(13). 提案するマスタスレーブシステムは, 図 1(b)に示すようなマス夕とスレーブが一体となる ものであり,このようなシステムをマスタスレーブー 体型ツール (Combined Master-Slave Tool) と呼ぶこ とにする. 以下 CMS ツールとする．本システムは, 従来人間が直接行っている微細作業スタイルの本質的 な変化を要求しておらず, 使用している道具をインテ リジェント化することで, 作業性を高めようとするも のである.

\section{C M S ツール}

$3 \cdot 1$ 磁気浮上磁気浮上の特徵は, 非接触, 無摩 擦であり, 高精度な位置・力制御が可能となり, 組立 作業へ応用されたり(15)，人工衛星のアンテナの指向制 御に適用されている(16). Salcudean ら ${ }^{(17)}$ は, ロボッ トアームの先端に磁気浮上系を組合せたスレーブマニ ピュレータを開発している，本研究では，マス夕側の 駆動力として電磁石による吸引力を用い, さらにツー ル自身を磁気浮上させることで操作性, 静粛性を高め 


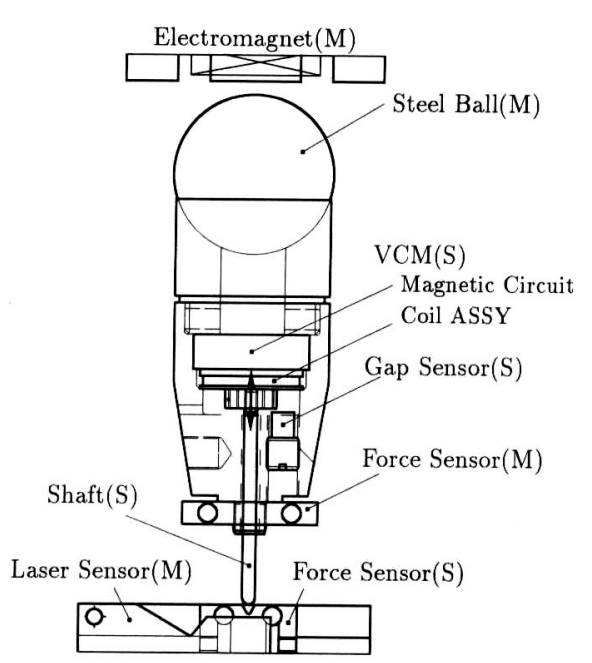

Fig. 2 Combined master-slave tool

る.

$3 \cdot 2$ 構造とセンサ系 図 2 は, 提案する CMS ツールの内部構造を示したものである. 全長 160 $\mathrm{mm}$, 直径 $50 \mathrm{~mm}$, 重量 $791 \mathrm{~g}$ で, 垂直方向の一軸直 動駆動機構である. 図中で, マス夕側は $(\mathrm{M})$, スレー ブ側は(S)で記されている. マスタは磁気浮上系, ス レーブはボイスコイルモータ (VCM)を備えている.

マスタ・スレーブそれぞれが，カセンサおよび位置セ ンサを一組備えている．図からわかるように, CMS ツールはマスタとスレーブが完全に構造的に一体化さ れている.

ツール本体(強化型ナイロン 6 , 不透明)の上部に鋼 球 $(\phi 50 \mathrm{~mm})$ が取付けられ, 外観上は一つの道具とし か見えないが, 中央部分に VCM[昭和電線(株), 4-1 $\mathrm{R}$ 直動型]が内蔵されている。 その性能を表 1 に示す. VCM は，磁石を内藏した磁気回路と実際に力を発生 するコイル ASSY の二つの部品から構成されている. 磁気回路および後述する非接触変位計は, ッール本体 内に固定されている.コイル ASSY にはシャフトが 取付けられており, 図 2 の矢印のように直線駆動され， 変位計でその相対変位が計測される.このシャフトが 本体下部から軸受けを介して伸びており，対象物に対 して操作が行われる. 鋼球と VCM は駆動の際の磁気 の影響を考慮して約 $30 \mathrm{~mm}$ 離してある。また，本体 は上下に 2 分割できるようになっている.

磁気浮上系で重要となる電磁石の設計仕様は次のよ うにした. 磁芯材料は, 磁束密度 $1.6 \mathrm{~T}$ 以上(磁化力 $5000 \mathrm{~A} / \mathrm{m}$ 時)である厚さ $0.5 \mathrm{~mm}$ の電磁鋼帯を長さ $70 \mathrm{~mm}$, 幅 $105 \mathrm{~mm}$, 中央脚の幅 $35 \mathrm{~mm}$, 外脚の幅
Table 1 Specifications of VCM

\begin{tabular}{|c|c|}
\hline Stroke & $4 \mathrm{~mm}$ \\
\hline Rating force & $1.65 \mathrm{~N}$ \\
\hline Max. force & $3.3 \mathrm{~N}$ \\
\hline Rating current & $1.0 \mathrm{~A}$ \\
\hline Max. current & $2.0 \mathrm{~A}$ \\
\hline
\end{tabular}

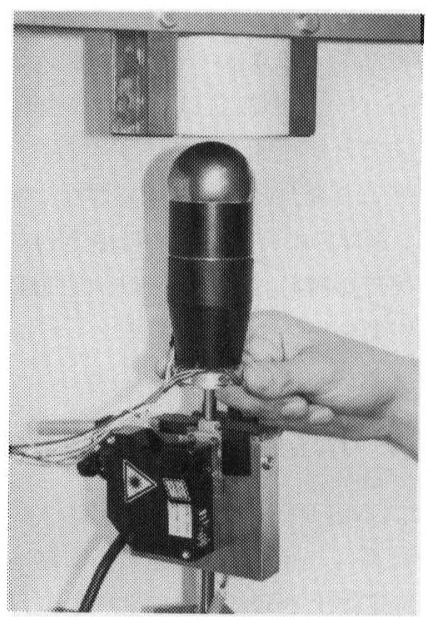

Fig. 3 Operation style

$17.5 \mathrm{~mm}$ の $\mathrm{E}$ 形形状にしたものを, 90 枚積層して奥 行き $45 \mathrm{~mm}$ とした。 その中央脚にコイルの巻線とし て直径 $0.7 \mathrm{~mm}$ のエナメル線(耐熱温度 $120^{\circ} \mathrm{C}$ ) を 900 turn 巻いた.これは, 電磁石と鋼球とのギャップ距離 $5 \mathrm{~mm}$ のところで, 出力電流值 $3 \mathrm{~A}$ のとき吸引力 $20 \mathrm{~N}$ を発生することができるょうになっている.

浮上体の位置は, 絶対座標系に固定されたレーザ式 変位センサ [松下電工(株), ANL-2334C］を用いて 計測し, VCM の変位は, 本体に内藏された渦電流非 接触変位計 [電子応用(株), AEC5507 型] で計測す る. それぞれの分解能は, $3.5 \mu \mathrm{m}(300 \mathrm{~Hz})$ および 0.5 $\mu \mathrm{m}(20 \mathrm{kHz})$ である.

マスタ用のカセンサは, 本体下部に取付けられてお り, スレーブ用のカセンサは, レーザセンサと同じ固 定台に取付けられている. ただし，本来なら VCM と シャフトの間に取付けるべきものだが, 本プロトタイ プでは，等価なシステムとしてこのような構造を採用 した. カセンサは, 平行平板構造を採用し, 構造材と してアルミニウム合金(A2024-T351)を使って自作し た. 出力電圧は, ひずみゲージアンプ(ユニパルス, $\mathrm{AM}-20$, ローパスフィルタ $150 \mathrm{~Hz})$ を通しコンピュー タに入力している. マスタおよびスレーブの力センサ

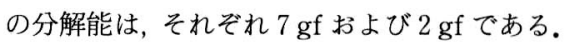

$3 \cdot 3$ 操作方法 本節では, 以降の議論の理解を 
深めるために, CMS ツールの操作方法についてその 概略を先に述べておく．図 3 に柔らかいゴムチューブ を実際に操作しているようすを示す，操作者は，本体 下部に取付けられたマスタ側の力センサを親指と人差 し指で軽くつまみ, 対象物をのぞき込む形でツールを 上下方向に動かし, シャフト先端で操作する.

マスタとして磁気浮上系を採用しているので, 非接 触で保持されていることから, 摩擦, ガ夕などから解 放され，CMS ッールを独立した一つの道具に近い状 態で操作することが可能となる.すなわち, 機械的に 強固に支持された場合に比べ拘束感がなく操作性がよ い.ただし，鋼球の中心まわりに自由運動を起こして しまうが, 実際の操作ではこの運動は問題にならな い. また, 作業を一時中断し, 手をツールから離して も安定な浮上状態にある。

\section{4. $\boldsymbol{H}_{\infty}$ 制御に基つく安定浮上}

本章では, CMS ツールの安定浮上について議論す る. 磁気浮上系は, 非線形性が強い不安定系であるた め, 実際に安定浮上させるためには, 電磁力を適切に 制御することが必要であり, 制御対象のパラメー夕変 動による制御系の不安定化を避けた補償器の設計が要 求される。

$4 \cdot 1$ パラメータ同定と線形モデル 理想的な磁 気浮上系を考え, 定常状態 $Z_{0}\left(z=Z_{0}+\Delta z\right), I_{0}\left(i=I_{0}\right.$ $+\Delta i)$ まわりで線形化すると, 次のような運動方程式 を得る。

$$
M \ddot{\Delta} z=\frac{Q I_{0}^{2}}{\left(Z_{\infty}+Z_{0}\right)^{3}} \Delta z-\frac{Q I_{0}}{\left(Z_{\infty}+Z_{0}\right)^{2}} \Delta i
$$

ここで,

$$
I_{0}=\sqrt{\frac{2 M g}{Q}}\left(Z_{\infty}+Z_{0}\right)
$$

$M$ は浮上体質量であり, $g$ は重力加速度である. $\Delta z$ は浮上体の位置の微小変化, $\Delta i$ は電磁不を流れる電 流の微小変化である. 次に, 磁気浮上系のパラメー夕 となる $Q, Z_{\infty}$ および $I_{0}$ の同定のための実験方法につ いて述べる。

本研究では, 川谷らが行った方法を用いて, パラメ

Table 2 Gap and current

\begin{tabular}{|c|c|}
\hline$Z\left[\times 10^{-3} \mathrm{~m}\right]$ & $I[A]$ \\
\hline \hline 2.15 & 1.188 \\
\hline 4.14 & 1.583 \\
\hline 6.27 & 1.906 \\
\hline 8.29 & 2.210 \\
\hline 10.06 & 2.511 \\
\hline 12.14 & 2.868 \\
\hline
\end{tabular}

一タの同定実験を次のように行った。まず，平衡点と なるギャップ長さ $Z_{0}$ を $5.00 \mathrm{~mm}$ に設定した。次に， 電磁石と浮上体上部の鋼球の間に, アクリル板 $(2 \sim 12$ $\mathrm{mm}$ まで $2 \mathrm{~mm}$ 刻みの 6 種類を準備した) を挟み, 浮 上体を吸引する。ここで，コイル電流を徐々に小さく してゆき, 浮上体が落下する瞬間の電流值を測定す る.同定実験から表 2 のような結果が得られた。

縦軸に電流 $I$, 横軸にアクリル板の厚さ (ギャップ 長さ) $Z$ をとってプロットし，最小二乗法によって直 線近似する。次に, 平衡状態の関係式である式 ( 2 ) よ り，システム定数 $Q ， Z_{\infty}$ を算出する．ただし，浮上体 質量 $M$ は $791 \mathrm{~g}$ である。結果として, 各パラメータ は次のように同定された。

$$
\begin{aligned}
& Q=5.72 \times 10^{-4} \mathrm{Hm}, Z_{\infty}=5.2 \times 10^{-3} \mathrm{~m}, \\
& I_{0}=1.69 \mathrm{~A}
\end{aligned}
$$

$x=[\Delta z, \dot{\Delta} z]^{T}, u=\Delta i$ として運動方程式を行列の形 で整理すると, 次のような線形モデルを得る。

$$
\left\{\begin{array}{l}
\dot{x}=\left[\begin{array}{cc}
0 & 1 \\
1.92 \times 10^{3} & 0
\end{array}\right] x+\left[\begin{array}{c}
0 \\
-11.7
\end{array}\right] u \\
y=\left[\begin{array}{ll}
1 & 0
\end{array}\right] x
\end{array}\right.
$$

CMS ツールは, 操作力が加えられても安定に浮上し 続けなければならない.そこで，操作力を等価的に浮 上体の質量変化と考え，質量変化を構造的不確かさと してモデル化する。すなわち，次式で表される構造的 不確かさを有するシステムを考える。

$$
\left\{\begin{array}{l}
\dot{x}=[A+\Delta A] x+[B+\Delta B] u \\
y=C x
\end{array}\right.
$$

ただし， $A, B$ および $C$ は式（３）に示すシステム行列 である. 6 章で示す実験での操作力の大きさを考慮し て, CMS ツールに $502 \mathrm{~g}$ の付加質量を付け，同様な同 定実験を行った結果，構造的不確かさとして，次のよ うな $\Delta A$ および $\Delta B$ を得た。

$$
\Delta A=\left[\begin{array}{cc}
0 & 0 \\
4 \times 10 & 0
\end{array}\right], \Delta B=\left[\begin{array}{c}
0 \\
2.6
\end{array}\right]
$$

$4 \cdot 2$ 二次安定化混合感度問題 本研究では, $4 \cdot 1$ 節で述べた制御対象のパラメータ変動 $\Delta A$ および $\Delta B$ に対するロバスト性を二次安定性で保証し，同時に低 感度特性を周波数重み関数によって指定する二次安定 化混合感度問題を適用する(18).

まず，構造的不確かさ $\Delta A, \Delta B$ および $\Delta C$ は正規化 定数行列 $D_{i}, E_{i}$ および時変行列 $F_{i}(i=1,2,3)$ を用い $\tau$,

$$
\left\{\begin{array}{l}
\Delta A=D_{1} F_{1} E_{1} \\
\Delta B=D_{2} F_{2} E_{2} \\
\Delta C=D_{3} F_{3} E_{3}
\end{array}\right.
$$




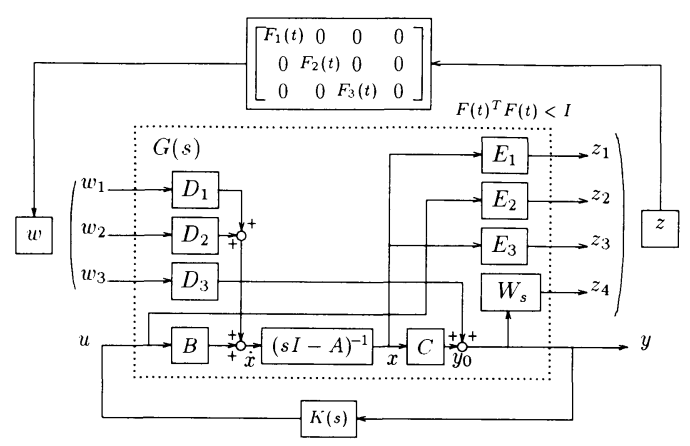

Fig. 4 Generalized plant

と表すことができる．ただし， $F_{i}(t)^{T} F_{i}(t)<I$ を満た すものとする。次に, 図 4 に示すような一般化制御対 象 $G(s)$ を考える.ここで, $w$ は参照入力や外乱など 外生信号であり, $z$ は制御量(一般的に小さくしたい 量)である.また, $u$ は操作量であり, $y$ は観測出力で ある. 制御則を,

$$
u=K(s) y
$$

と定め, フィードバック系を構成する. 二次安定であ るための十分条件は,

1. 閉ループ系が安定

2. $\|\Phi(s)\|_{\infty}<1$

が成立することである，ただし， $\Phi(s)$ は, 外生信号 $w$ から制御量 $z$ までの伝達関数であり, \|\|$_{\infty}=$ $\sup _{\omega} \bar{\sigma}(・)[\bar{\sigma}(\cdot)$ は最大特異值 $]$ である(10).この十 分条件の下で問題を解き, 解が存在するならばその補 償器は二次安定化補償器である.

$4 \cdot 3$ 補償器設計 式( 3 )に示す設計モデルの定 常ゲインが $0 \mathrm{~dB}$ 以上となるように, 等価的に $C$ 行列 を 200 倍する. また, 正規化定数行列を以下のように おいた。

$$
\begin{aligned}
& D_{1}=\left[\begin{array}{l}
0 \\
d_{1}
\end{array}\right], D_{2}=\left[\begin{array}{l}
0 \\
d_{2}
\end{array}\right], D_{3}=d_{3} \\
& E_{1}=\left[\begin{array}{ll}
e_{1} & 0
\end{array}\right], E_{2}=e_{2}, E_{3}=\left[\begin{array}{ll}
e_{3}(=0) & 0
\end{array}\right]
\end{aligned}
$$

ここで, 先に得られた構造的不確かさ $\Delta A, \Delta B$ より次 の関係式が成り立つ.

$$
d_{1} e_{1}=4 \times 10, d_{2} e_{2}=2.6, d_{3} e_{3}=0
$$

状態量と操作量のトレードオフを表現する配分比率 $E_{1}: E_{2}$ は, $120: 1$ (操作量の抑制を重視)とした。ま た, オブザーバゲインを調整する配分比率 $D_{1}: D_{3}$ は, $6.39: 1$ とした. 制御性能に影響を与えない配分比率 $D_{1}: E_{1}$ は $1: 1$ とした.これらの配分比率と式(7) より, 正規化定数行列 $D_{i}, E_{i}$ の各要素が次のように 决定された。

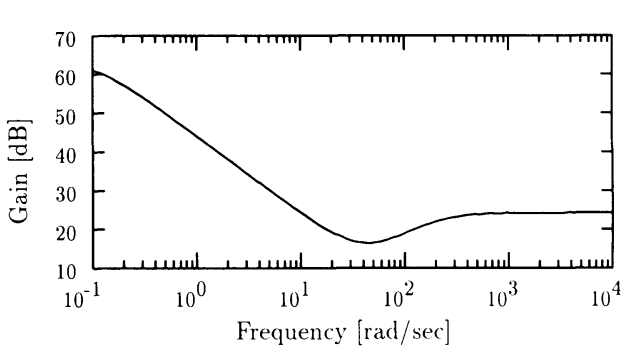

Fig. $5 \quad H_{\infty}$ controller

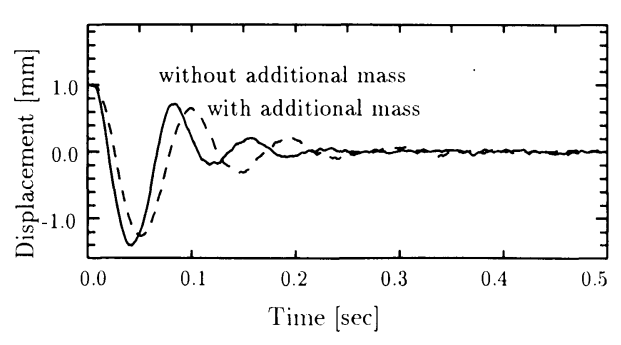

Fig. 6 Step response

$$
\begin{aligned}
& d_{1}=\sqrt{4 \times 10}, d_{2}=2.6 / e_{2}, d_{3}=1 \\
& e_{1}=\sqrt{4 \times 10}, e_{2}=e_{1} / 120, e_{3}=0
\end{aligned}
$$

さらに, 低感度化に対する重み関数 $W_{s}$ は, 次のよう にした.

$$
W_{s}=\frac{20}{d_{3}(s+0.1)}
$$

以上の点を考虑して, 一般化制御対象の状態空間表 現を導出し, 制御系設計 CAD (MATLAB) を用い, 適 当な $\gamma$-iterationを行って解を求めた. 低感度化を実 現する二次安定化補償器 $K(s)$ を次のように得た.

$$
\begin{aligned}
& K(s)=\frac{4.65 \times 10^{7}(s+37.2 \pm 19.2 j)}{(s+0.1)(s+181)\left(s+2.85 \times 10^{6}\right)} \\
& \gamma=0.869
\end{aligned}
$$

図 5 は補償器のゲイン特性である.図 6 はステップ 応答の実験結果である. ただし, 破線は $502 \mathrm{~g}$ の付加 質量が取付けられた場合である。図 6 からわかるよう に,オーバーシュートが見られるものの高応答を実現 し, 安定浮上を達成している。 また, 付加質量によっ て系が不安定になることもなく, 操作力が加わっても 浮上が維持できることがわかる.

\section{5. バイラテラル制御}

$5 \cdot 1$ 力帰還型 図 7 は, CMS ツールのモデルを

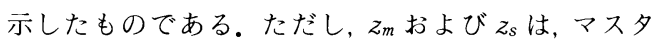
およびスレーブの変位であり， $u_{m}$ および $u_{s}$ は，それ ぞれ電磁石の吸引力およびVCM の推力である。ま た，対象物としてばね剛性をもったものを考える。 


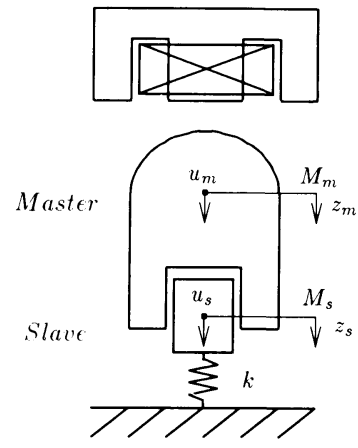

Fig. 7 Model of CMS tool

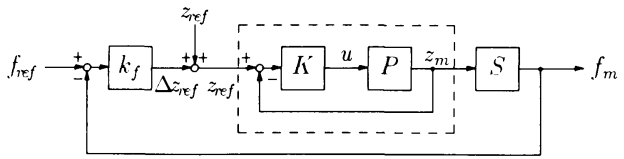

Fig. 8 Block diagram of force control

基礎実験の段階として, 次のような力㷌還型のバイ ラテラル制御則を採用した。

$$
\left\{\begin{array}{l}
u_{m}=-f_{s}+k_{m}\left(A_{f} f_{m}-f_{s}\right) \\
u_{s}=k_{p}\left(A_{z} z_{m}-z_{s}\right)+k_{v}\left(A_{z} \dot{z}_{m}-\dot{z}_{s}\right)
\end{array}\right.
$$

$f_{m}, f_{s}$ は，それぞれ操作者がマス夕に加える力および スレーブが対象物から受ける力である。 また， $A_{f}, A_{z}$ は, マスタとスレーブの間の力および位置の増幅率で ある、スレーブは,アクチュエータとしてVCM を用 いているため，usに関する制御則は直接実現できる. 一方，マス夕は，磁気浮上系の吸引力を利用している が, 4 章で述べた安定浮上制御が必須であり, 直接, 式 （10）に基づいた $u_{m}$ の制御は行えない. そこで, 本研 究では, $5 \cdot 2$ 節で述べる間接的な力制御に基づくバイ ラテラル制御を提案する。

$5 \cdot 2$ 力制御方式 一般に, 力制御方式は次の二 つに大別できる、一つは，力と運動の関係を制御する 間接的な力制御. もう一つは, 力を直接制御する直接 的な力制御である。本研究では，マス夕の磁気浮上系 において直接力制御することは困難であるため, 図 8 に示すような位置制御を基礎とした間接的な力制御方 式を採用する，以下にその具体的な制御則を示す。

下位レベル マスタである磁気浮上系は, 4 章で述 べたように二次安定化補償器を用いて位置制御されて いる。ここでは，その制御則を以下のように置き換え る.

$u=K(s)\left(z_{\text {ref }}-z_{m}\right)$

ここで, $K(s)$ は二次安定化補償器であり，z $z_{\text {ref }}$ は上位 レベルで生成される位置目標值である。

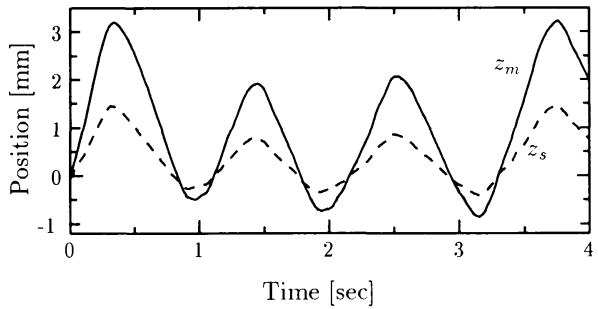

Fig. 9 Free motion $\left(A_{z}=0.4\right)$

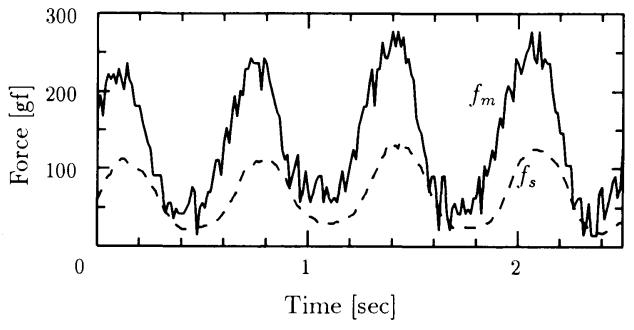

Fig. 10 Constrained motion $\left(A_{z}=0.1, A_{f}=0.5\right)$

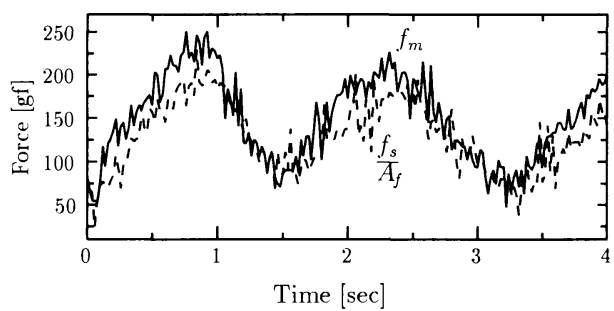

Fig. 11 Constrained motion $\left(A_{z}=0.5, A_{f}=0.25\right)$

上位レベル 上位レベルでは，位置目標值 $z_{r e f}$ を次 式のように与える.

$$
\left\{\begin{array}{l}
z_{r e f}=z_{r e f}+\Delta z_{r e f} \\
\Delta z_{r e f}=k_{f}\left(f_{r e f}-f_{m}\right)
\end{array}\right.
$$

式(12)からわかるように， $z_{r e f}$ はサンプリングタイム ごとに更新される形をとっている， $f_{r e f}$ はマス夕の力 目標值であり，次式に示すように本研究では力帰還型 の制御則を適用している。

$$
f_{r e f}=-f_{s}+k_{m}\left(A_{f} f_{m}-f_{s}\right)
$$

\section{6. 実 験 結 果}

CMS ツールを用いた操作実験を行った $(3 \cdot 3$ 節参 照). 制御コンピュータには, PC - 9821Xp (NEC, 486DX4，100 MHz)を用いた。サンプリングタイムは $1 \mathrm{~ms}$ であった。

$6 \cdot 1$ 自由運動 まず, 図 9 に対象物に接触して いない浮上状態での自由運動の場合の実験結果を示 す. $A_{z}=0.4$ とした. 横軸は時間, 縦軸は位置を示し 
ている，ただし，実線がマス夕の位置 $z_{m}$, 破線がスレ 一ブの位置 $z_{s}$ を示している. 図からわかるように, 指定した位置の増幅率 $A_{z}$ を満たしている.このとき の操作周波数は約 $1 \mathrm{~Hz}$ 程度である.

6.2 拘束運動 次に, 図 3 に示すように柔らか いゴムチューブを操作した場合の実験結果を示す。図 10 および図 11 に実験結果を示す. 図 10 は, $A_{z}=1.0$, $A_{f}=0.5$ とした場合の力の時間変化を示している. ま た, 図 11 は, $A_{z}=0.5, A_{f}=0.25$ とした場合の実験結 果を示している。ただし, 図 11 に関しては, 指定した 力の増幅率を満たしているかよくわかるように $f_{s} / A_{f}$ を破線で図示している。これらの図からわかるよう に, センサノイズの影響はあるものの, ほほ指定した 増幅率 $A_{f}$ を達成しており満足がいくものである.

$6 ・ 1$ 節での実験と同様, 操作力を加えても安定浮上 を維持できることが確認できた．また，本実験では， 電磁石の発熱の問題はなかった. 将来的には, ツール のさらなる小型化を行えば, 浮上制御によるエネルギ 一消費は軽減されると考えられる。これに伴い熱の発 生も小さくなる.

\section{7. 結 論}

道具を使った人間の自然な作業スタイルを変えずに 微細作業が行える小型の道具をイメージした新しい夕 イプのマスタスレーブシステムを開発した. 以下に得 られた結果をまとめる。

（1）アクチュエー夕およびセンサを一組備えたマ スタとスレーブを構造的に一体化し, 小型の道具(ツ ール)としてコンパクトにまとめ上げた。外観上は, 一つの道具としか見えず, マスタによりスレーブを操 作しているという意識を生じさせない.

（2）マスタとして, 非接触で摩擦のない磁気浮上 系を採用することで, CMS ツールを独立した一つの 道具に近い状態で操作することが可能となり, 機械的 に強固に保持された場合に比べ操作性を高めた。ま た, 磁気浮上系の安定化制御のために, 二次安定化手 法を適用し, さらに低感度特性を考慮した混合感度問 題により制御系設計を行った。このとき, 操作力を等 価的に浮上体の質量変化として捉え, 質量変化を構造 的不確かさとしてモデル化した.

（3）位置と力の増幅率を考慮した力㷌還型のバイ ラテラル制御を採用した。ここで, 安定浮上制御が必 須であるマス夕に対し，位置制御を基礎とした間接的 な力制御方式を適用した。

(4) 操作実験の結果から, 操作力を加えても安定 浮上を維持できることを確認し, 指定どおりの増幅率
で操作可能であることを実証した。

今後, バイラテラル制御系における補償器設計を $H_{\infty}$ 制御理論の枠組みの中で行っていく予定であ $3^{(19)}$. 本研究の一部は, 文部省科学研究費 [奨励研究 (A) 07750290] および(財) メカトロニクス技術高度化 財団の援助のもとで行われたものである. 最後に, 磁 気浮上に関して, 適切なご助言をいただいた長岡技術 科学大学川谷亮治先生に深く感謝する.

\section{文献}

（1）佐藤知正・畑村洋太郎, マイクロマニピュレーション, 日 本ロボット学会誌, 12-4 (1994), 560-565.

(2) 特集, テレロボティクスの理論, 日本ロボット学会誌, 116 (1993), 769-827.

（3） 横小路泰義・細谷徳男・吉川恒夫, マイクロテレオペレ ーションの操作性と安定性, 第 11 回日本ロボット学会学 術講演会予稿集, 3 (1993), 1053-1054.

( 4 ) Sato, T., Ichikawa, J., Mitsuishi, M. and Hatamura, Y., Micro Teleoperation System Concentrating Visual and Force Information at Operator's Hand, Proc. of the 3rd Int. Symp. Experimental Robotics, (1993), 353-365.

（5）中尾政之・矢野崇史 - 浅井亮介 - 畑村洋太郎, 微小力制 御可能な外科手術用掘削工具の開発, 1996 年度精密工学 会春季大会講演会講演論文集, (1996), 337-338.

（6）松日楽信人・朝倉誠・番場弘行・植之原道広, 高性能又 スタスレーブマニピロレータの開発, 第 2 回ロボットシ ンポジウム予稿集, (1992), 145-150.

(7) Kazerooni, H., Human-Robot Interaction via the Transfer of Power and Information Signals, IEEE Trans. Systems, Man, and Cybernetics, 20-2 (1990), 450463.

（8）福田敏男・藤澤佳生・新井史人・ほか 5 名, マン・ロポ ット協調作業型マニピュレータの基礎的研究 (第 1 報, 、 ン・ロボット協調マニピュレータの機構と制御)，機論， 57-541, C(1991), 2944-2952.

（9）小菅一弘・藤澤佳生・福田敏男, 仮想ツールダイナミク スに基づくマン・マシン系の制御，機論， 60-572，C (1994), 1337-1341

（10）美多勉, $H_{\infty}$ 制御，(1994)，58-61，昭晃堂.

（11）坂口正道・佐野明人・古荘純次, $H_{\infty}$ 制御に基づくロボッ トアームのインピーダンス制御, 機論, 62-596, C(1996), 1503-1509.

(12) Green, P. S., Hill, J. W., Jensen, J.F. and Shah, A., Telepresence Surgery, IEEE Engineering in Medicine and Biology Magazine, 14-3 (1995), 324-329.

（13）佐野明人・小谷和也・村瀬康弘・藤本英雄, マイクロマ ニピュレーションのためのマスタスレーブー体型ツール の開発, 日本機械学会ロボティクス・メカトロニクス講 演会論文集, (1995)，1412-1415.

(14) Taylor, R. H., Funda, J., ほか 7 名. A Telerobotic Assistant for Laparoscopic Surgery, IEEE Engineer. ing in Medicine and Biology Magazine, 14-3 (1995), $279-288$.

（15）樋口俊郎 - 津田匡博, RCC 機能をもつ磁力支持方式精密 自動組立用ハンドの設計, 昭和 62 年度精密工学会春季大 会講演会論文集, (1987), 421-422.

（16）新宮悉太, 磁気浮上形位置決め機構の設計法(第 1 報, ア クチュエータ系のシンセシスと非干涉化の機構構造的設 計法), 機論, 55-518, C(1989), 2559-2568.

(17) Salcudean, S. E. and Wong, N. M., Coarse-Fine Motion 
Coordination and Control of a Teleoperation System with Magnetically Levitated Master and Wrist, Proc. of The 3rd Int. Symp. Experimental Robotics, (1993), 406-421.

（18）土井智晴・川谷亮治, 2 次安定化による磁気浮上系のロバ
スト制御, 計測自動制御学会論文集, 30-12（1994），14921498.

（19）佐野明人・藤本英雄, マスタスレーブ一体型ツールの $H_{\infty}$ 周波数分離制御, 第 5 回インテリジェント FA シンポジ ウム講演論文集, (1995)，43-44 